\title{
Methodology for in vitro Assessment of Human T Cell Activation and Blockade
}

Joseph R. Podojil' ${ }^{1}$ Igal Ifergan ${ }^{1}$, Ming-Yi Chiang ${ }^{1}$, Joshua J. Meeks ${ }^{2,3}$ and Stephen D. Miller ${ }^{1,4, *}$

${ }^{1}$ Dept. of Microbiology-Immunology, Feinberg School of Medicine, Northwestern University, Chicago, IL, USA; ${ }^{2}$ Department of Urology, Feinberg School of Medicine, Northwestern University, Chicago, IL, USA; ${ }^{3}$ Biochemistry and Molecular Genetics, Feinberg School of Medicine, Northwestern University, Chicago, IL, USA; ${ }^{4}$ Interdepartmental Immunobiology Center, Feinberg School of Medicine, Northwestern University, Chicago, IL, USA

*For correspondence: s-d-miller@northwestern.edu

[Abstract] Methods to test both the functionality and mechanism of action for human recombinant proteins and antibodies in vitro have been limited by multiple factors. To test the functionality of a recombinant protein or antibody, the receptor, the receptor-associated ligand, or both must be expressed by the cells present within the in vitro culture. While the use of transfected cell lines can circumvent this gap, the use of transfected cell lines does not allow for studying the native signaling pathway(s) modulated by the specific recombinant protein or antibody in primary cells. The present protocol utilizes sort purified $\mathrm{CD} 14^{+}$monocytes and $\mathrm{T}$ cells, both $\mathrm{CD} 4^{+} \mathrm{T}$ cells and $\mathrm{CD} 8^{+} \mathrm{T}$ cells, from healthy donors in a co-culture system. This methodology is particularly relevant for testing recombinant proteins or antibodies that are putative therapeutics for the treatment of autoimmune disease and cancer. While the current protocol focuses on co-cultures containing B7-H4 expressing monocytes plus either autologous $\mathrm{CD}^{+} \mathrm{T}$ cells or $\mathrm{CD} 8^{+} \mathrm{T}$ cells, the protocol can be modified for the user's specific needs.

Keywords: PBMCs, Human CD14 ${ }^{+}$monocytes, Human CD4 ${ }^{+} \mathrm{T}$ cells, Human $\mathrm{CD} 8^{+} \mathrm{T}$ cells, Co-culture, B7-H4

[Background] The clinical use of checkpoint inhibitor therapy, e.g., anti-CTLA-4 and anti-PD-1, has proven useful as a cancer therapy to enhance the anti-tumor immune response (Curran et al., 2010; Gubin et al., 2014). While successful in patients that have failed frontline therapy, only approximately $20 \%$ of treated patients responded to checkpoint inhibitor antibody therapy. This inactivity of treatment in a patient may be multifactorial, and may also be reflective of the specific type of cancer that a patient presents with to the clinician (Podojil et al., 2020). B7-H4 expression by tumor cells and monocyte/macrophages present within the tumor is an additional putative mechanism by which tumor cells evade anti-tumor immune responses (Salceda et al., 2005; Simon et al., 2007; Qian et al., 2011; Abadi et al., 2013). Based on these published findings, the expression of B7-H4 within the tumor microenvironment, i.e., by the tumor cells and/or by infiltrating monocyte/macrophages, is hypothesized to allow for tumor cells to evade an anti-tumor immune response via both direct inhibition of effector $T$ cell function and increasing regulatory $\mathrm{CD}^{+}{ }^{+} \mathrm{T}$ cell function (Wei et al., 2011; Podojil et al., 2013).

The development of in vitro methods to determine the functionality of immunological therapeutics for the treatment of human disease has relied heavily on the use of cell lines. However, while there are 
similarities between the signaling pathways activated within human T cells lines (Jurkat and HuT78) and primary $\mathrm{T}$ cells isolated from PBMCs, there are distinct differences between the level of signaling pathway intermediate activation, the timing/longevity of signaling pathway intermediate activation, and the cytokine profile expressed between human T cells lines and primary T cells (Bartelt et al., 2009). For example, besides IL-2, both Jurkat and HuT78 cells are less depenent upon costimulation and secreted significantly lower levels of T cell effector cytokines, such as IL-4, IL-5, IL-17, TNF- $\alpha$, and IFNY upon T cell receptor stimulation (Bartelt et al., 2009). This finding limits the utility of these cell lines when studying the ability of a recombinant protein or antibody to modulate cellular activities outside of T cell proliferation and IL-2 production.

The present method can be used to determine the functionality of therapeutics utilizing primary monocytes, $\mathrm{CD}^{+} \mathrm{T}$ cells, and $\mathrm{CD} 8^{+} \mathrm{T}$ cells purified from healthy human donors. Several cellular considerations for determining the functionality and identifying/validating the mechanism of action for a putative checkpoint inhibitor are required for assay development. The assay must be fit-for-purpose, robust, repeatable, and transferable between collaborating laboratories. In the present example for the study of anti-B7-H4 functional activity, cells that express B7-H4 must be present within the culture system, i.e., a macrophage population that has been pre-conditioned in the presence of recombinant human cytokines to induce the expression of $\mathrm{B} 7-\mathrm{H} 4$. Additionally, the $\mathrm{B} 7-\mathrm{H} 4$ receptor must be expressed by a target immune cell population, i.e., T cells. The B7-H4 receptor is expressed by a sub-set of both $\mathrm{CD}^{+} \mathrm{T}$ cells and $\mathrm{CD}^{+} \mathrm{T}$ cells following activation (Podojil et al., 2013). Therefore, an additional consideration for the present experimental design is that since the $\mathrm{B} 7-\mathrm{H} 4$ receptor is not present at high levels on freshly isolated T cells, the response rate within the co-culture system will display donor-todonor variation.

To this end, two general model are presented below. The first model utilized co-culture of $\mathrm{B} 7-\mathrm{H} 4$ expressing human macrophages with autologous purified $\mathrm{CD} 4^{+} \mathrm{T}$ cells, and the second model system utilized co-culture of $\mathrm{B} 7-\mathrm{H} 4$ expressing human macrophages with autologous purified $\mathrm{CD} 8^{+} \mathrm{T}$ cells. In brief, $\mathrm{CD} 14^{+}$monocytes are isolated from total PBMCs, and the CD14 $4^{+}$monocytes are cultured in the absence or presence of IL-10 and IL- 6 for 3 days. Both $C D 4^{+} T$ cells and $C D 8^{+} T$ cells are isolated from the CD14- cell fraction of the healthy donor PBMC samples. The sort purified $\mathrm{CD} 4^{+} \mathrm{T}$ cells and $\mathrm{CD} 8^{+} \mathrm{T}$ cells are cryopreserved for future co-culture with the B7-H4 expressing macrophages. Figure 1 presents the number of each cell population isolated from twelve healthy donor PBMC samples. Following the initial 3 day macrophage culture in the presence of IL-10 and IL-6, the macrophages are harvested. The data show that macrophages cultured in the absence of IL-10 and IL- 6 do not express B7-H4, while macrophages cultured in the presence of IL-10 and IL-6 do express B7-H4 (Podojil et al., 2020). On day 3 , the cryopreserved autologous $\mathrm{CD} 4^{+} \mathrm{T}$ cells and $\mathrm{CD} 8^{+} \mathrm{T}$ cells are rapidly thawed, washed, and labeled with CFSE. The $\mathrm{CD}^{+}{ }^{+} \mathrm{T}$ cells and $\mathrm{CD} 8^{+} \mathrm{T}$ cells are then co-cultured with IL-10 plus IL- 6 conditioned macrophages in the presence of plate-bound anti-CD3 plus either a species and isotype matched Control antibody or anti-B7-H4. On day 6 of the assay (day 3 of macrophage-T cell co-culture) the level of $\mathrm{CD}^{+} \mathrm{T}$ cell and $\mathrm{CD} 8^{+} \mathrm{T}$ cell proliferation is assessed via flow cytometry (CFSE dilution), and the levels of secreted cytokine, such as IFN- $\gamma$, determined in the culture supernatants. While the use of 
transfected cell lines is a useful tool to quickly screen large numbers of recombinant proteins and antibodies for potential biological activity, the present protocol using primary cells allows for the validation of the initial in vitro cell line culture findings.

\section{Materials and Reagents}

1. $50 \mathrm{ml}$ conical tubes (CentriStar tube, orange cap) (Corning, catalog number: 430828)

2. $15 \mathrm{ml}$ conical tubes (CentriStar tube, orange cap) (Corning, catalog number: 430790)

3. 6-well tissue culture plates (Costar, catalog number: 3516)

4. 96-well flat bottom tissue culture plates (Costar, catalog number: 3596)

5. Falcon Round-Bottom Tubes, $5 \mathrm{ml}$ with snap cap (Corning, catalog number: 352054)

6. Human peripheral blood buffy coats (LifeSource)

7. Ficoll-Paque PLUS (GE Healthcare, catalog number: 17-1440-03)

8. 1x DPBS without $\mathrm{Ca}^{2+}$ and $\mathrm{Mg}^{2+}$ (Gibco, catalog number: 2017-07)

9. EDTA (0.5 M, pH 8.0) (Invitrogen, catalog number: 15575020)

10. Fetal calf serum (Benchmark ${ }^{\mathrm{TM}}$ Fetal Bovine Serum) (Gemini Bio-Products, catalog number: 100-106)

11. Liquid nitrogen

12. RPMI 1640 Medium without glutamine (Invitrogen, catalog number: 21870-100)

13. MEM non-essential amino acid solution (Sigma-Aldrich, catalog number: M7145-100 ml)

14. L-glutamine-200 mM (100x) (Invitrogen, catalog number: 25030-081)

15. Penicillin-Streptomycin (Invitrogen, catalog number: 15140-122)

16. 2-mercaptoethanol (1,000x) (Gibco, catalog number: 21985-023)

17. HEPES (1 mM) (Gibco, catalog number: 15630-080)

18. Sodium pyruvate (100 mM solution with $8.5 \mathrm{~g} / \mathrm{L} \mathrm{NaCl}$ (VWR, catalog number: 25-000-Cl)

19. Trypan blue solution, $0.4 \%$ (Invitrogen, catalog number: 15250061)

20. CD14 Isolation Kit (Miltenyi, CD14 MicroBeads, human, catalog number: 130-050-201)

21. CD4 Isolation Kit (Miltenyi, CD4 ${ }^{+} \mathrm{T}$ Cell Isolation Kit, human, catalog number: 130-096-533)

22. CD8 Isolation Kit (Miltenyi, CD8 ${ }^{+} \mathrm{T}$ Cell Isolation Kit, human, catalog number: 130-096-495)

23. Human recombinant IL-6 (R\&D Systems, catalog number: 206-IL/CF)

24. Human recombinant IL-10 (R\&D Systems, catalog number: 217-IL/CF)

25. CellTrace ${ }^{\mathrm{TM}}$ CFSE Cell Proliferation Kit, for flow cytometry (Thermo Fisher, catalog number: C34554)

26. Anti-CD3 (clone OKT3) (Invitrogen, catalog number: 16-0037-81)

27. Viability stain (VID)-LIVE/DEAD ${ }^{\mathrm{TM}}$ Fixable Aqua Dead Cell Stain Kit, for $405 \mathrm{~nm}$ excitation (Thermo Fisher, catalog number: L34965)

28. Fc Block-Fc Receptor Binding Inhibitor Polyclonal Antibody, Functional Grade, eBioscience ${ }^{\mathrm{TM}}$ (Thermo Fisher, catalog number: 16-9161-73)

29. Anti-CD4 APC, clone OKT4 (Thermo Fisher, catalog number: 17-0048-42) 
30. Anti-CD8 APC, clone 3B5 (Thermo Fisher, catalog number: MHCD0805)

31. $1 x$ DPBS $+2 \mathrm{mM}$ EDTA (500 ml) (see Recipes)

32. $1 \times$ DPBS $+5 \%$ FCS $(500 \mathrm{ml})$ (see Recipes)

33. Completed RPMI Medium (1,000 ml) (see Recipes)

34. Cell Freezing Medium (2x stock) (see Recipes)

\section{Equipment}

1. Pipettes

2. Sterile hood

3. $-80{ }^{\circ} \mathrm{C}$ freezer with a Mr. Frosty Freezing container

4. Centrifuge (Thermo Scientific ${ }^{\mathrm{TM}}$ Sorvall ${ }^{\mathrm{TM}} \mathrm{ST}$ 8FR Centrifuge)

5. Incubator (Thermo Scientific ${ }^{\mathrm{TM}}$ Forma ${ }^{\mathrm{TM}}$ Steri-Cult ${ }^{\mathrm{TM}} \mathrm{CO}_{2}$ Incubators)

6. Water bath

7. Inverted phase contrast microscope

8. autoMACS Pro Separator (Mitenyi Biotec)

9. Flow cytometer (BD FACSCanto cytometer, BD Biosciences)

10. MAGPIX Luminex 200 (Millipore)

\section{Software}

1. FlowJo Version 10.5.3 (FlowJo)

2. XPONENT software (Millipore)

\section{Procedure}

\section{Day 0: PBMC Isolation}

Note: All steps in the present protocol should be completed in a sterile hood, using sterile technique, and all reagents should be sterile.

1. Obtain human peripheral blood buffy coats or whole blood from healthy donors. The cell number data presented in Figure 1 below are based on the use of $50 \mathrm{ml}$ buffy coat samples. 


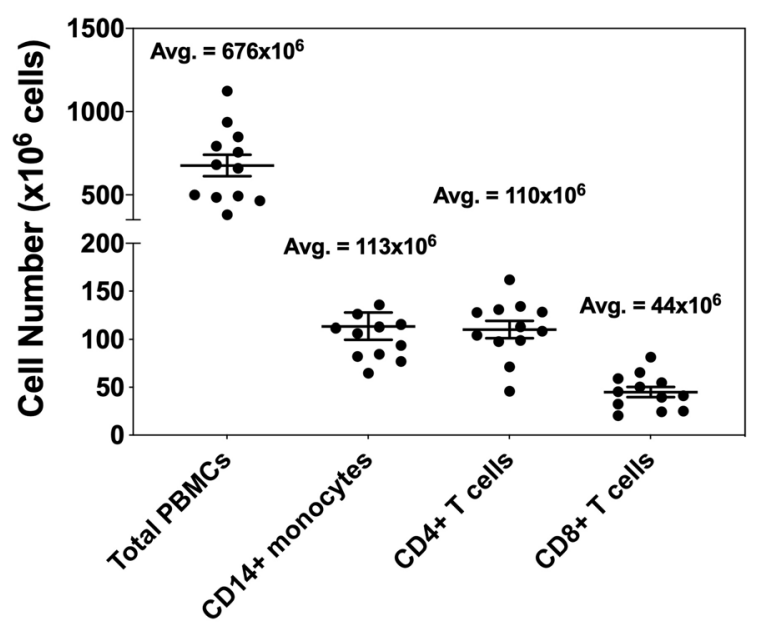

Figure 1. Cell numbers obtained for total PBMCs, CD14 ${ }^{+}$cells, $C D 4^{+} \mathrm{T}$ cells, and $\mathrm{CD}^{+} \mathrm{T}$ cells. Buffy coats from healthy donors $(n=12)$ were obtained from LifeSource. First total PBMCs were collected via centrifugation with a Ficoll-Paque PLUS gradient. The collected PBMCs were counted, and CD14 ${ }^{+}$cells sort purified. The CD14- cells were further separated into $\mathrm{CD} 4^{+} \mathrm{T}$ cell and $\mathrm{CD} 8^{+} \mathrm{T}$ cell populations via sorting. The data are presented as the number of obtained cells, with the average cell numbers presented above each indicated population.

2. Resuspend the buffy coat cells $1: 1$ volumetrically in 1x DPBS. For example, add $25 \mathrm{ml}$ of $1 \mathrm{x}$ DPBS to a $50 \mathrm{ml}$ conical, and $25 \mathrm{ml}$ of the buffy coat sample. The buffy coat-DPBS mixture should be evenly mixed via pipetting.

3. In a separate $50 \mathrm{ml}$ conical add $15 \mathrm{ml}$ of Ficoll-Paque PLUS, and then overlay $35 \mathrm{ml}$ of the above buffy coat-DPBS mixture.

4. Centrifuge the layered tubes of buffy coat-DPBS mixture plus Ficoll-Paque PLUS at $400 \times g$ for $30 \mathrm{~min}$ at room temperature with the break turned off on the centrifuge.

5. Following the spin, collect the PBMC layer and place the PBMCs into a fresh $50 \mathrm{ml}$ conical. See the following link for the manufacturer's support protocol (https://cdn.gelifesciences.com/dmm3bwsv3/AssetStream.aspx?mediaformatid=10061\&destin ationid $=10016 \&$ assetid $=12637$ ).

6. Centrifuge the $50 \mathrm{ml}$ conical tubes containing the PBMCs at $300 \times \mathrm{g}$ for $10 \mathrm{~min}$ to pellet the PBMCs.

7. Wash the PBMC pellet 3 times with $30 \mathrm{ml}$ of $1 \times$ DPBS, and the PBMCs should be pelleted via centrifugation at $300 \times \mathrm{g}$ for $10 \mathrm{~min}$.

8. Following the last wash, count the PBMCs using a hemocytometer.

\section{Day 0: CD14 ${ }^{+}$monocyte isolation and culture}

1. Place $500 \times 10^{6}$ of the PBMCs cells into a $15 \mathrm{ml}$ conical tube to complete the CD14+ monocyte isolation via the use of human CD14 positive selection beads (Miltenyi, CD14 MicroBeads, human, 130-050-201) following the manufacturer protocol. Both the CD14+ cell and CD14- cell 
fractions should be saved, as the $\mathrm{CD}_{1} 4^{+}$cell fraction will be cultured in the presence of recombinant human cytokine to generate the $\mathrm{B} 7-\mathrm{H}^{+}$macrophages for the macrophage- $\mathrm{T}$ cell co-culture portion of the protocol. The CD14- cell fraction will be used to sort purify either the $\mathrm{CD}^{+} \mathrm{T}$ cells or $\mathrm{CD}^{+} \mathrm{T}$ cells required for the macrophage- $\mathrm{T}$ cell co-culture portion of the protocol.

2. Culture the purified $\mathrm{CD} 14^{+}$cells at $5 \times 10^{6}$ cells $/$ well $\left(2.5 \times 10^{6} \mathrm{cells} / \mathrm{ml}\right)$ in 6 -well plates. The final volume present in each well is $2 \mathrm{ml}$ of complete RPMI medium.

3. At the initiation of culture, the desired final concentration of recombinant human cytokine(s) is added to the respective wells containing $\mathrm{CD} 14^{+}$cells. The present protocol uses recombinant human IL-10 plus IL-6 (at a final concentration of $10 \mathrm{ng} / \mathrm{ml}$ ) to induce the expression of B7-H4 on the surface of the resultant macrophages collected on day 3 post culture. However, the recombinant cytokines used can be altered to allow for the expression of the desired surface molecules on the $\mathrm{CD} 14^{+}$cells post culture.

4. Culture the $\mathrm{CD} 14^{+}$monocytes at $37^{\circ} \mathrm{C}$ in the presence of $5 \% \mathrm{CO}_{2}$ for 3 days.

\section{Day 0: $\mathrm{T}$ cell isolation and cryopreservation}

1. From the CD14- cell population collected above, place these cells into either a human $\mathrm{CD} 4^{+} \mathrm{T}$ cell Automax sort (Miltenyi, CD4 ${ }^{+}$T Cell Isolation Kit, human, catalog number: 130-096-533) or human $\mathrm{CD}^{+} \mathrm{T}$ cell Automax sort (Miltenyi, $\mathrm{CD} 8^{+} \mathrm{T}$ Cell Isolation Kit, human, catalog number: 130-096-495). The manufacturer protocol should be followed.

2. The purified $\mathrm{CD}^{+} \mathrm{T}$ cells and $\mathrm{CD} 8^{+} \mathrm{T}$ cells should be counted and cryopreserved at $10 \times 10^{6}$ cells $/ \mathrm{ml}$ with $2 \mathrm{ml}$ of cells per tube in cell freezing medium.

3. To do so, pellet the T cells at $300 \times g$ for $10 \mathrm{~min}$, and resuspend the T cells in completed RPMI and adjust concentration at $20 \times 10^{6} \mathrm{cell} / \mathrm{ml}$.

4. Mix the T cells $\left(20 \times 10^{6}\right.$ cells $\left./ \mathrm{ml}\right) 1: 1$ volumetrically with the freezing medium by slowly adding the freezing medium drop-wise to the T cells, and then rapidly aliquot cells into pre-labeled cryovial tubes, such that the final cell concentration of T cells per tube is $10 \times 10^{6} \mathrm{cells} / \mathrm{ml}$.

5. The $T$ cells should be frozen overnight in the $-80^{\circ} \mathrm{C}$ freezer with a Mr. Frosty Freezing container (or a Styrofoam box works as well). The cells should be transferred to liquid nitrogen the following morning.

\section{Day 3: T cell preparation for macrophage-T cell co-culture}

1. Pull vial(s) of frozen $\mathrm{T}$ cells out of the liquid nitrogen, and rapidly thaw the cells in a $37^{\circ} \mathrm{C}$ water bath.

2. Transfer the thawed $\mathrm{T}$ cells $(\sim 2 \mathrm{ml}$ of $\mathrm{T}$ cells in freezing medium) to a $15 \mathrm{ml}$ conical (Corning CentriStar tube, orange cap) and add $10 \mathrm{ml}$ of complete RPMI medium.

3. Spin the cells down at $300 \times g$ for $10 \mathrm{~min}$.

4. Wash the cells 3 times with $10 \mathrm{ml}$ of $1 \times$ DPBS. 
5. Count the T cells collected from the cryovials, and the T cells will next be labeled with CFSE prior to setting up the macrophage-T cell co-cultures.

6. CFSE labeling of T cells.

a. Wash the $T$ cells 3 times with $1 \times$ DPBS, and following the last wash resuspend the $T$ cells at $20 \times 10^{6} \mathrm{cells} / \mathrm{ml}$ in $1 \times$ DPBS.

b. Prepare an equal volume of $0.8 \mu \mathrm{M}$ CFSE in $1 \times$ DPBS in separate tube.

c. Quickly add the CFSE mixture to the tube containing the T cells. The final concentration of CFSE is then $0.4 \mu \mathrm{M}$ within the tube containing the T cells to be stained.

d. Cover the tube containing the $T$ cells with foil, and incubate the $T$ cells at room temperature for 8 min with gentle rocking.

e. To quench the CFSE staining reaction, add $0.5 x$ volume of sterile FCS and mix the tube containing the $T$ cells by inverting, and incubate the tube at room temp with gentle rocking for an additional $5 \mathrm{~min}$.

f. Following the CFSE quenching step, spin tube containing the CFSE-labeled T cells at $300 \times g$ for $10 \mathrm{~min}$ and wash the T cells 2 times with $15 \mathrm{ml} 1 \times$ DPBS.

g. Recount the T cells before using in desired application.

7. Resuspend the T cells at $5 \times 10^{6} \mathrm{cells} / \mathrm{ml}$ in complete RPMI medium.

8. The T cells are now ready to be added to the co-culture wells.

\section{Day 3: Macrophage preparation for co-culture}

1. Remove the 6-well plates containing the IL-10 and IL-6 conditioned CD14+ cells from the incubator, and gently swirl the plate to remove the non-adherent cells. Remove and discard the $2 \mathrm{ml}$ of medium containing the non-adherent cells. The present protocol utilizes the live adherent cells, i.e., macrophages.

2. To harvest the macrophages, add $1 \mathrm{ml}$ of $1 \times$ DPBS containing $2 \mathrm{mM}$ EDTA, and incubate the plates at $37^{\circ} \mathrm{C}$ for $15 \mathrm{~min}$.

3. Following the above incubation, add $2 \mathrm{ml}$ of complete RPMI medium to each well and collect the cells. Be sure to pipette mix each well thoroughly while limiting the amount of bubble formation, such that as many macrophages as possible can be collected.

4. Pellet the collected macrophages via centrifugation at $300 \times \mathrm{g}$ for $10 \mathrm{~min}$, wash the cells 3 times with complete RPMI medium, and count the macrophages.

5. Resuspend the macrophages at $1 \times 10^{6} \mathrm{cell} / \mathrm{s} / \mathrm{ml}$ in complete RPMI medium.

6. The IL-10 plus IL-6 conditioned macrophages are ready to be added to the co-culture wells.

\section{Day 3: Set up of the co-culture wells}

1. For the IL-10 plus IL-6 conditioned macrophage and CFSE-labeled T cell co-cultures, the cells are cultured in flat-bottomed 96 -well plates. 
2. Prior to the addition of the macrophages and T cells, coat the flat-bottomed 96-well plate with anti-CD3 $\left(0.5 \mu \mathrm{g} / \mathrm{ml}, 100 \mu \mathrm{l} /\right.$ well, coating wells for $2 \mathrm{~h}$ at $37^{\circ} \mathrm{C}$, wells washed 3 times with $1 \mathrm{x}$ DPBS).

3. Following the coating of the culture plate wells with anti-CD3, wash the wells 3 times with $200 \mu \mathrm{l} / \mathrm{well}$ of $1 \mathrm{x}$ DPBS.

4. After washing the culture plate wells and removing the 1x DPBS wash volume via aspiration, add $100 \mu \mathrm{l} /$ well (equaling $1 \times 10^{5}$ cells/well) of the IL-10 plus IL- 6 conditioned macrophage macrophages from above.

5. Add $50 \mu \mathrm{l} /$ well (equaling $2.5 \times 10^{5}$ cells/well) of the CFSE-labeled T cells from above.

6. Add the appropriate amount of species and isotype Control antibody or anti-B7-H4 contained within $50 \mu \mathrm{l}$ of complete RPMI. For example, if final concentration of Control Ab or anti-B7-H4 is $10 \mu \mathrm{g} / \mathrm{ml}$ within the well, Control Ab or anti-B7-H4 should be diluted to $40 \mu \mathrm{g} / \mathrm{ml}$ in completed RPMI, such $50 \mu \mathrm{l}$ of the working stock of Control Ab or anti-B7-H4 can be added to each respective well.

7. Incubate the IL-10 plus IL- 6 conditioned macrophage and CFSE-labeled $\mathrm{T}$ cell co-cultures at $37^{\circ} \mathrm{C}$ in the presence of $5 \% \mathrm{CO}_{2}$ for 3 days.

\section{Day 6: Analysis}

1. Remove the co-culture plates from the incubator, and gently swirl the plate to remove the nonadherent cells. Collect the non-adherent cells via pipette mixing the wells, transfer the cells into a clean FACS tube.

2. The non-adherent cells will be analyzed via flow cytometric staining for Live/CD4 ${ }^{+} \mathrm{T}$ cells and Live/CD8 ${ }^{+} \mathrm{T}$ cells to assess the level of $\mathrm{T}$ cell proliferation as determined by CFSE dilution.

3. Spin the cells down at $300 \times g$ for $10 \mathrm{~min}$, and collect the supernatant into clean microfuge tubes. The supernatants will can be used fresh or frozen at $-80^{\circ} \mathrm{C}$, and the level of secreted IFN- $\gamma$ measured via either Luminex or ELISA.

4. Wash the pelleted cells 3 times with $10 \mathrm{ml}$ of $1 \times$ DPBS.

5. Following the last wash, incubated the cells with $100 \mu \mathrm{L}$ LIVE/DEAD ${ }^{\mathrm{TM}}$ Fixable Aqua Dead Cell Stain $\left(1: 1,000\right.$ in $1 x$ DPBS) for 20 min at $4{ }^{\circ} \mathrm{C}$ in the dark.

6. Wash the cells 3 times with $1 \times$ DPBS $+5 \%$ FCS.

7. Following the last wash, incubated the cells with $100 \mu \mathrm{l}$ of Fc Receptor Binding Inhibitor Polyclonal Antibody (1:100 dilution in 1x DPBS $+5 \%$ FCS) for 20 min at $4{ }^{\circ} \mathrm{C}$ in the dark.

8. Wash the cells 3 times in $1 \times$ DPBS $+5 \%$ FCS.

9. Following the last wash, incubated the cells with $100 \mu$ of either anti-CD4 APC or anti-CD8 APC (1:100 dilution in $1 \times$ DPBS $+5 \% \mathrm{FCS}$ ), respectively, for 20 min at $4{ }^{\circ} \mathrm{C}$ in the dark.

10. Wash the cells 3 times with $1 \times$ DPBS, and resuspended in $300 \mu \mathrm{l}$ of $1 \times$ DPBS $+5 \%$ FCS, and analyzed on the flow cytometer. 


\section{Data analysis}

1. At the end of co-culture, cell culture supernatants should be collected to assess the level of secreted cytokine. The culture supernatant may need to be diluted up to 1:10 in complete RPMI prior to analysis via Luminex or ELISA. The level of secreted cytokine is reported (Podojil et al., 2020).

2. For the flow cytometric analysis of the $T$ cell proliferation data, the Live/CD4 ${ }^{+} \mathrm{T}$ cells or Live/CD8 ${ }^{+}$ $T$ cells should be gated into a flow cytometry histogram to assess the dilution of CFSE. Examples of the CFSE gating scheme is presented in Figure 2. The percentage of $\mathrm{CD} 4^{+} \mathrm{T}$ cells and $\mathrm{CD}^{+} \mathrm{T}$ cells that have proliferated, i.e., diluted CFSE, is reported (Podojil et al., 2020).
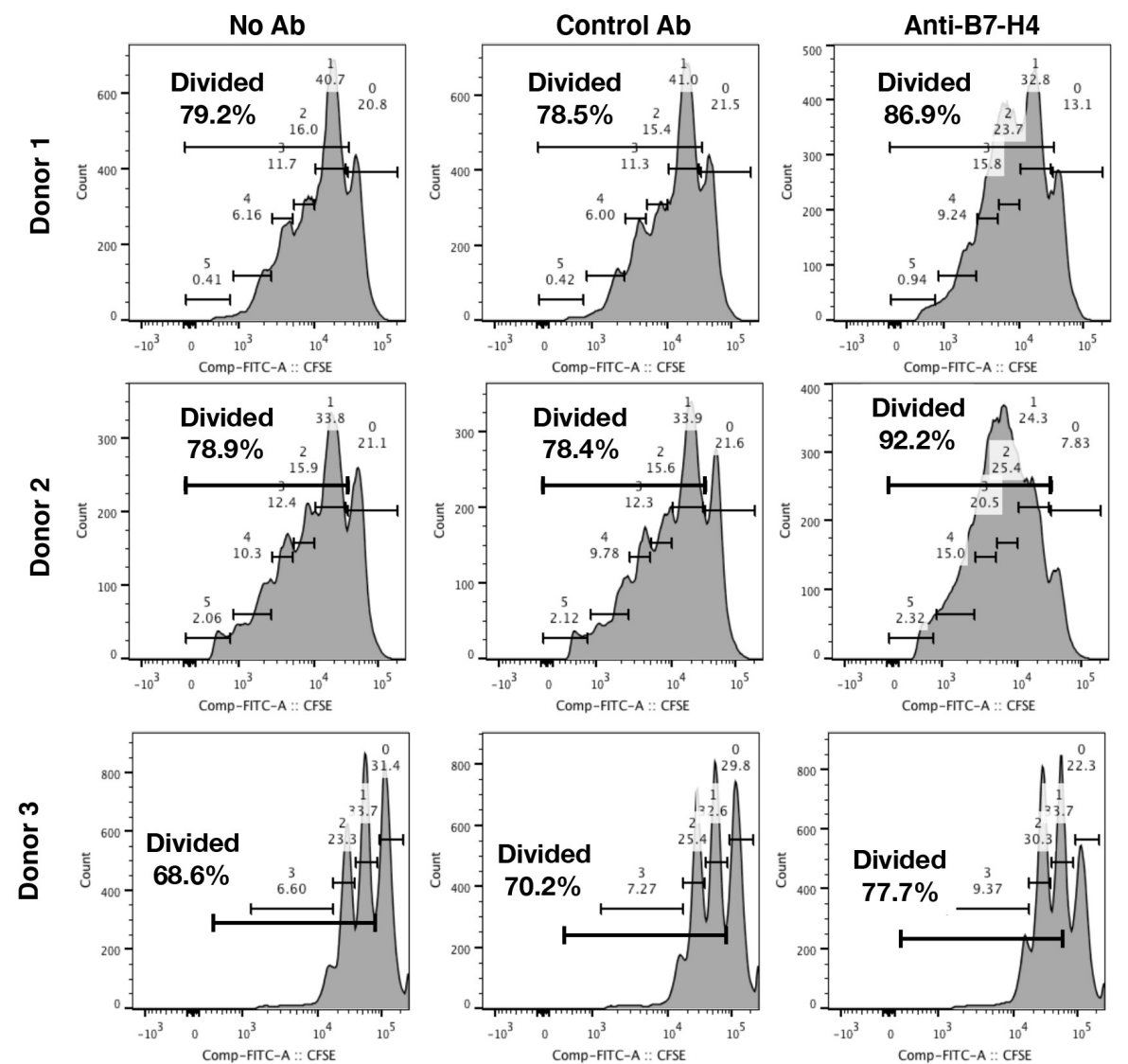

Figure 2. Analysis of $\mathrm{CD4}^{+} \mathrm{T}$ cell dilution of CFSE on Day 6. For the assessment of T cells proliferation, the T cells were collected, washed in PBS, stained with LIVE/DEAD ${ }^{\circledR}$ Fixable Aqua Dead Cell Stain, blocked with Fc block, and then stained with the anti-CD4 (clone OKT4) or antiCD8 (clone 3B5) respectively. The T cells samples were analyzed on a flow cytometer, and the resulting data analyzed using the following gating scheme; Singlets (FSC-H vs. FSC-A) -> Live cells (SSC-A vs. Viability stain negative) $->\mathrm{CD} 4^{+}$cells. Flow cytometric histograms for three representative donors assessing the percentage of divided $\mathrm{CD} 4^{+} \mathrm{T}$ cells are presented. The reported results are expressed as the mean percentage of proliferated $\mathrm{CD} 4^{+}$and $\mathrm{CD} 8^{+} \mathrm{T}$ cells. 


\section{$\underline{\text { Notes }}$}

1. Buffy coats $(50 \mathrm{ml})$ from LifeSource were obtained for the present analyses. It is critical to use fresh cells, as $\mathrm{CD} 14^{+}$monocytes purified from cryopreserved PBMC samples do not respond as robustly.

2. The figures present the expected cell numbers obtained from $50 \mathrm{ml}$ buffy coat samples following each step, i.e., the total PBMC isolation, the $\mathrm{CD} 14^{+}$monocyte sort, the $\mathrm{CD} 4^{+} \mathrm{T}$ cell sort, and the $\mathrm{CD}^{+} \mathrm{T}$ cell sort (Figure 1). The gating for to determine the percentage of live $\mathrm{CD} 4^{+} \mathrm{T}$ cells that have proliferated within the co-culture with $\mathrm{B} 7-\mathrm{H}^{+}$macrophages on day 6 (day 3 of co-culture) is in presented in Figure 2.

3. The ability of using previously activated $C D 4^{+} T$ cells and $C D 8^{+} T$ cells has also been tested to determine if a higher response rate to anti-B7-H4 treatment as compared to Control $\mathrm{Ab}$ treatment can be obtained utilizing the presence co-culture system. The hypothesis being that since the $\mathrm{B} 7-\mathrm{H} 4$ receptor is induced on $\mathrm{CD} 4^{+} \mathrm{T}$ cells and $\mathrm{CD} 8^{+} \mathrm{T}$ cells following activation, this would increase the percentage/number of $T$ cells within the IL-10 plus IL- 6 conditioned macrophage and CFSE-labeled T cell co-cultures that could be modulated by the addition of anti-B7-H4. However, the data show that while activated $C D 4^{+} T$ cells and $C D 8^{+} T$ cells do in fact proliferated to a greater extent as compared to cryopreserved $\mathrm{CD} 4^{+} \mathrm{T}$ cells and $\mathrm{CD} 8^{+} \mathrm{T}$ cells, this increased level of activation may mask the ability to detect an anti-B7-H4-induced increase in activity.

\section{Recipes}

1. $1 x$ DPBS $+2 \mathrm{mM}$ EDTA $(500 \mathrm{ml})$

$498 \mathrm{ml}$ of $1 \times$ DPBS without $\mathrm{Ca}^{2+}$ and $\mathrm{Mg}^{2+}$

$2 \mathrm{ml}$ of EDTA (0.5 M, pH 8.0)

2. $1 \times$ DPBS $+5 \%$ FCS $(500 \mathrm{ml})$

$975 \mathrm{ml}$ of $1 \times$ DPBS without $\mathrm{Ca}^{2+}$ and $\mathrm{Mg}^{2+}$

$25 \mathrm{ml}$ of FCS

3. Completed RPMI Medium (1,000 ml)

849 ml RPMI 1640 Medium without glutamine

$100 \mathrm{ml}$ of FCS

$10 \mathrm{ml}$ of MEM non-essential amino acid solution

$10 \mathrm{ml}$ of L-glutamine-200 mM (100x)

$10 \mathrm{ml}$ of Penicillin-Streptomycin

$10 \mathrm{ml}$ of Sodium pyruvate (100 $\mathrm{mM}$ solution with $8.5 \mathrm{~g} / \mathrm{L} \mathrm{NaCl}$ )

$10 \mathrm{ml}$ of HEPES ( $1 \mathrm{mM})$

$1 \mathrm{ml}$ of 2-mercaptoethanol $(1,000 \mathrm{x})$

4. Cell Freezing Medium (2x stock) 


\author{
$20 \%$ DMSO \\ $80 \%$ FBS
}

\title{
Acknowledgments
}

Development of this protocol was partially funded by NIH grant NS30871.

\section{Competing interests}

The authors have no financial or non-financial competing interests relative to this protocol.

\section{Ethics}

For the completion of the present assay, the research must have IRB approval for the collection of whole blood from healthy donors. For the author presented data, the buffy coat samples were purchased from LifeSource. The authors received the buffy coat samples both coded and blinded, and the IRB was maintained by LifeSource.

\section{$\underline{\text { References }}$}

1. Abadi, Y. M., Jeon, H., Ohaegbulam, K. C., Scandiuzzi, L., Ghosh, K., Hofmeyer, K. A., Lee, J. S., Ray, A., Gravekamp, C. and Zang, X. (2013). Host b7x promotes pulmonary metastasis of breast cancer. J Immunol 190(7): 3806-3814.

2. Bartelt, R. R., Cruz-Orcutt, N., Collins, M. and Houtman, J. C. (2009). Comparison of T cell receptor-induced proximal signaling and downstream functions in immortalized and primary $T$ cells. PLoS One 4(5): e5430.

3. Curran, M. A., Montalvo, W., Yagita, H. and Allison, J. P. (2010). PD-1 and CTLA-4 combination blockade expands infiltrating $T$ cells and reduces regulatory $T$ and myeloid cells within B16 melanoma tumors. Proc Natl Acad Sci U S A 107(9): 4275-4280.

4. Gubin, M. M., Zhang, X., Schuster, H., Caron, E., Ward, J. P., Noguchi, T., Ivanova, Y., Hundal, J., Arthur, C. D., Krebber, W. J., Mulder, G. E., Toebes, M., Vesely, M. D., Lam, S. S., Korman, A. J., Allison, J. P., Freeman, G. J., Sharpe, A. H., Pearce, E. L., Schumacher, T. N., Aebersold, R., Rammensee, H. G., Melief, C. J., Mardis, E. R., Gillanders, W. E., Artyomov, M. N. and Schreiber, R. D. (2014). Checkpoint blockade cancer immunotherapy targets tumour-specific mutant antigens. Nature 515(7528): 577-581.

5. Podojil, J. R., Glaser, A. P., Baker, D., Courtois, E. T., Fantini, D., Yu, Y., Eaton, V., Sivajothi, S., Chiang, M., Das, A., McLaughlin, K. A., Robson, P., Miller, S. D. and Meeks, J. J. (2020). Antibody targeting of $\mathrm{B} 7-\mathrm{H} 4$ enhances the immune response in urothelial carcinoma. Oncoimmunology 9(1): 1744897. 
6. Podojil, J. R., Liu, L. N., Marshall, S. A., Chiang, M. Y., Goings, G. E., Chen, L., Langermann, S. and Miller, S. D. (2013). B7-H4lg inhibits mouse and human T-cell function and treats EAE via IL-10/Treg-dependent mechanisms. J Autoimmun 44: 71-81.

7. Qian, Y., Shen, L., Cheng, L., Wu, Z. and Yao, H. (2011). B7-H4 expression in various tumors determined using a novel developed monoclonal antibody. Clin Exp Med 11(3): 163-170.

8. Salceda, S., Tang, T., Kmet, M., Munteanu, A., Ghosh, M., Macina, R., Liu, W., Pilkington, G. and Papkoff, J. (2005). The immunomodulatory protein B7-H4 is overexpressed in breast and ovarian cancers and promotes epithelial cell transformation. Exp Cell Res 306(1): 128-141.

9. Simon, I., Katsaros, D., Rigault de la Longrais, I., Massobrio, M., Scorilas, A., Kim, N. W., Sarno, M. J., Wolfert, R. L. and Diamandis, E. P. (2007). B7-H4 is over-expressed in early-stage ovarian cancer and is independent of CA125 expression. Gynecol Oncol 106(2): 334-341.

10. Wei, J., Loke, P., Zang, X. and Allison, J. P. (2011). Tissue-specific expression of B7x protects from CD4 T cell-mediated autoimmunity. J Exp Med 208(8): 1683-1694. 